Article | Special Issue

\title{
Toward an Aesthetic Community: A Manifesto for a Revolution to Come ${ }^{1}$
}

Jesus Emmanuel S. Villafuerte

\begin{abstract}
The artist has been given a much-privileged role in modern society; a profession which in earlier times was considered not different from other types of professions is now regarded in higher esteem, indeed not just as another form of labor but a divine calling. In modern times, the artist has become a sort of god himself, a creator. It is thus without surprise that the artist-creator, with the awareness of his special role in society, has claimed more than once, and in varying ways, the autonomy of his position and his art; for the artist-creator, art is detached from the exigencies of class conflict, and can circumvent the politics and ideology that operate in the production of almost everything, from chairs and utensils to cultural artefacts, under this era of global capitalism. Art has veered away from its original ethicorepresentative logic and has closely resembled a cult that asks for uncritical veneration. Theodor Adorno for his part, offers a negation of this arrogant belief. He mentions in his last book and magnum opus, Aesthetic Theory, that "for absolute freedom in art, always limited to a particular, comes into contradiction with the perennial unfreedom of the whole." 2 This specific passage questions the notion of freedom in art, or its possibility of truly being free, in relation to the general unfreedom being experienced by man. With this in mind, I will attempt to engage the artist's perception of his superiority and offer ways on how he could reformat his modes of thinking and making. First, I will discuss the historical circumstances that caused the elevation of the artist's position and perception in society; second, I will discuss the rise of the curator, the prophet of the museums and galleries, and how his recognition of his power or lack thereof could play a vital role in ushering the museums and galleries of the future; third, I will talk
\end{abstract}

${ }^{1}$ An earlier version of this paper bearing the title "The Task of the Artist in a Systematized Society: A Manifesto for A Revolution to Come" was presented at the First Kritike Conference: Critical Theory at the Margins held at the Martyrs' Hall, University of Santo Tomas, 1-2 December 2017.

2 Theodor Adorno, Aesthetic Theory, ed. by Gretel Adorno and Rolf Tiedemann, trans. and ed. by Robert Hullot-Kentor (London: Bloomsbury, 2004), 1.

(c) 2019 Jesus Emmanuel S. Villafuerte

https://www.kritike.org/journal/special issue/villafuerte april2019.pdf

ISSN 1908-7330

$(c c)$ BY-NC-ND 
about the tasks of the artist and his art in this era where genuine freedom is almost impossible to achieve; and fourth, drawing from Rancière, I will argue that the artist must leave the museums and galleries and forge connections with the common people, in order to "invent new models of social relations," which would ultimately lead to the creation of an aesthetic community.

Keywords: aesthetic community, curator, artistic resistance, homo aestheticus

\section{Burn the Museums, Ransack the Galleries}

\footnotetext{
"There is no art without eyes that see it as art." - Jacques Rancière, The Future of the Image
}

$\mathrm{T}$

There was a point in history when artistic objects, instead of being fetishized commodities sold at auction houses for hefty, almost scandalous, amounts, had utilitarian purpose because they were deeply rooted in the community. Rancière calls this mode of artistic production as the ethical regime of art, which is "characteristic of Platonism" and "is primarily concerned with the origin and telos of imagery in relationship to the ethos of the community. It establishes a distribution of images - without, however, identifying 'art' in the singular-that rigorously distinguishes between artistic simulacra and the 'true arts' used to educate the citizenry concerning their role in the communal body." ${ }^{3}$ The divide between simulacra and the true arts, between art as a poor imitation of reality and art as a vessel of didactic discourse, because exhibiting and emphasizing the necessity of an individual's participation in the community, would be the primary concern of artificers and philosophers for a long time. But this model of artistic production proved to be unsustainable. As the artistic practice developed over time, it was imperative that new models of artistic production would be formed. In Rancière's cartography of artistic modes, what followed the ethical regime is the representative regime. This regime is "an artistic system of Aristotelian heritage" in which imitation and simulacra have been liberated "from the constraints of ethical utility and isolates a normatively autonomous domain with its own rules for fabrication and criteria of evaluation." 4 In the representative regime, art lost its ethical value and became divorced from the idea of the community-during the advent of the representative regime, the artist started viewing himself as an autonomous

3 Gabriel Rockhill, Translator's Introduction to Jacques Rancière, The Politics of Aesthetics: The Distribution of the Sensible, trans. by Gabriel Rockhill (London: Continuum, 2004), 4.

${ }^{4}$ Ibid., 4.

(c) 2019 Jesus Emmanuel S. Villafuerte https://www.kritike.org/journal/special issue/villafuerte april2019.pdf ISSN 1908-7330 


\section{TOWARD AN AESTHETIC COMMUNITY}

figure, a creature with special faculties that must be treated differently from the rest of the society.

At the turn of the $19^{\text {th }}$ century, the representative regime of the artistic order, which was the primary mode of artistic practice at that time, was superseded by the aesthetic regime of art. The representative regime, until then, had been the dominant force in the artistic landscape. In this regime, there is rigidity in terms of subject matter for the arts, meaning, not everything can be represented and transformed into art. In some ways, this specific artistic mode functioned as an extension, albeit a rewired one, of the ethical regime of the arts which originated during the time of Plato. While both the ethical and representative regimes carried the logic of "mimesis," the representative regime, which effected a break from the ethical regime, is different in that representation in this particular regime had lost its ethical value, whereas representation in the ethical regime served a utilitarian purpose while simultaneously critiquing "visual simulacra."

In the current aesthetic regime of art, representation has been democratized, as Rancière would say in his book The Future of the Image, in the advent of the latest regime: "there are no longer appropriate subjects for art ... but a general availability for all subjects for all artistic form whatsoever," that is, in the current regime "hierarchies, and genres, and subject matter" have been effectively overturned and replaced, which, in effect, liquefied the borders of art. ${ }^{5}$ Van Gogh's A Pair of Shoes, a painting depicting a worn and overused pair of peasant shoes would not have been a viable artistic piece during the time of the Renaissance when artistic pieces aside from portraying biblical moments, portrayed the extravagance of kings and nobles.

During the time of the shift to the new regime, the commodification of art intensified: critics would consider the establishment of museums and galleries as one of the main contributing factors to this, which is correct, but oftentimes the critique stops at this point, which is disastrous as it does not explain the historical condition responsible for the rise of museums and galleries. What should be mentioned is that the rise of galleries and museums was brought about by the rise of industrial capitalism in Europe. And when capital started expanding, it overturned the old feudalistic modes of production, and this expansionist logic of capital, which operated initially in the economic aspect of social relations, eventually exercised its dominance over the field of artistic production. While capital's exercise of dominance over economic and artistic fields arguably did not happen simultaneously but rather at very close intervals, we cannot deny that after World War I, when

${ }^{5}$ Jacques Rancière, The Future of the Image, trans. Gregory Elliott (London: Verso, 2009), 118.

(c) 2019 Jesus Emmanuel S. Villafuerte https://www.kritike.org/journal/special issue/villafuerte april2019.pdf ISSN 1908-7330

(c) $)$ BY-NC-ND 
kingdoms and empires collapsed and the geopolitical boundaries of the world were re-established, different (not necessarily new) modes of artistic practices emerged and were put under the spotlight: for example, literary works would gain popularity because of mass market paperbacks and film would establish itself as a legitimate form of art that is different from the theater, from which, many argue, it originated. That art is not art without eyes that see it as such means that what is art is based solely on perception. It is a construct of the ruling ideology.

The galleries and museums helped expand the market of artworks, and by giving these artworks a common space where they could be observed and marveled at, removed from the walls and hallways of ordinary homes, museums and galleries effectively perched the status of the artwork as similar to that of the creations of God: one has to go to the church to worship God who created the universe; one has to go to the museum to admire a painting created by an artist. This commodification of art would be a recurring object of theoretical critiques, philosophical treatises, and manifestoes. The museum is a space where the sensible is created, where the passive spectators get interpellated. Rancière says that a museum "is not only a specific building but also a form of apportioning the common space and a specific mode of visibility." 6 A common sensorium is created in the museum, this sensorium is then transferred and distributed among those who visit it.

Some artists have recognized the necessity to critique this fetishism and the existing relations in the mode of production in creative industries. In 1974, artist Gustav Mertzger provided a two-paragraph manifesto when he was asked to participate in an exhibit by the London Institute of Contemporary Arts titled Art into Society - Society into Art: Seven German Artists. The manifesto calls for fellow artists to stop making art for a period of three years, because for him, "the total withdrawal of labor is the most extreme challenge that artists can make to the state."7 Raunig explains that this call by Mertzger is an attempt to "break through the dialectic of 2009), 69.

${ }^{6}$ Jacques Rancière, The Emancipated Spectator, trans. by Gregory Elliott (London: Verso,

${ }^{7}$ Here is Mertzger's entire text: "Throughout the entire twentieth century, artists have attacked the prevailing methods of production, distribution and consumption of art. These attacks on the organization of the art world have gained momentum in recent years. This struggle, aimed at the destruction of existing commercial and public marketing and patronage systems, can be brought to a successful conclusion in the course of the present decade.

"The refusal to labour is the chief weapon of workers fighting the system: artists can use the same weapon. To bring down the art system, it is necessary to call for years without art, a period of three years-1977-1980 - when artists will not produce work, sell work, permit work to go on exhibitions, and refuse collaboration with any part of the publicity machinery of the art world. This total withdrawal of labour is the most extreme collective challenge that artists can make to the state." As quoted in Gerald Raunig, Factories of Knowledge: Industries of Creativity, trans. by Aileen Derieg (Los Angeles, CA: Semiotext(e), 2013), 138.

(c) 2019 Jesus Emmanuel S. Villafuerte https://www.kritike.org/journal/special issue/villafuerte april2019.pdf ISSN 1908-7330 
destruction and creation." 8 The roles of artists imposed by the market are either as a creator or as a destroyer; Mertzger provided a possible escape from this dichotomy. The radical logic behind Mertzger's solution must be talked about. He compared the labor of the artists to that of the proletarians, the common wageworkers; with this, he arrived at the solution that to paralyze the art market, artists should imitate what the workers do when they try to paralyze the capitalist system, that is, participate in strikes.

During the 1968 student revolt in France, one of the most famous slogans of the revolutionaries was "l'art est mort, ne consommez pas son cadavre" which translates to "art is dead, do not consume its corpse." 9 This death that we speak of does not necessarily mean the death or collapse of artistic modes and systems; rather, what the revolutionaries of May 1968 refer to with death is the bourgeosification of art that has stymied its liberative potential, and how because of this very same bourgeoisificaion, art veered away from its original ethical purpose of educating individuals about their function in the community. It is art's historical role that died. The slogan is important as it shows a specific form of resistance to the prevailing notion of art, exposing its contradictions and offering an agenda to change it. But as radical as slogans could be, they, paraphrasing Deleuze and Guattari in What Is Philosophy? do not survive the triumph or failure of revolutions. Slogans exist in the moment of the revolution, at particular and specific temporal junctures and become obsolete afterwards, once the new system has been introduced. As we all know, the 1968 student revolt would fail and would create disillusionment among its participants. And Rancière would even go so far as to say that the 1968 student revolt in France equipped capital in a time of crisis with new ideas, and new weapons, in dealing with contrary movements. And yet, failures as they may appear to some, it is up to us to derive from these failures lessons that we can utilize in our future engagements with enemies.

In Germany, in the '50s, Theodor Adorno became infamous among scribes for his pronouncement in the essay Cultural Criticism and Society that "to write poetry after Auschwitz is barbaric."10 This passage is often misinterpreted or read reductively as saying that art has reached a point when it has become obsolete or useless. Indeed, this misreading is most unfortunate as it fails to underscore the issue at which Adorno was pointing his finger and instead makes Adorno appear as if he was an incorrigible pessimist (which we can argue that he was but that requires another paper)

\footnotetext{
${ }^{8}$ Ibid., 137.

9 See Red Marriott, "Slogans of 68," in libcom.org (30 April 2008), $<$ https://libcom.org/history/slogans-68>.

10 Theodor Adorno, Prisms, trans. by Samuel Weber and Shierry Weber (Cambridge: MIT Press, 1997), 34.

(c) 2019 Jesus Emmanuel S. Villafuerte https://www.kritike.org/journal/special issue/villafuerte april2019.pdf ISSN 1908-7330
}

(c) BY-NC-ND 
who believed that beauty can never be achieved especially after an event as dreadful as World War II. ${ }^{11}$ What Adorno really meant was that poetry, as part and symptom of the project of enlightenment which signifies the new heights achieved by the intellect of man, has become a failure because enlightenment which was supposed to bring about civilization, progress, and all the positive values that come with it, such as harmony, technological advancement, and so on, has instead brought war, doom and countless deaths, and fascist regimes. Art was even used as a channel for spreading propaganda. Even artists, who supposedly are the "antennae of the race," supported openly and even in secret fascist leaders. ${ }^{12}$ Everyone is familiar with the anecdote that when the Valkyrie played at an opera house in Israel, the Jews in the audience stood up and walked out, rage visible on their faces, because Wagner, the composer of the piece, while did not openly support the Nazis, had been a huge influence on them in promoting German nationalism. Hence, the end of poetry or the barbarism of poetry is necessarily the manifestation of what Adorno calls the irresistible regression which is the curse of irresistible progress. What Adorno effectively says is that if the project of enlightenment is a failure, continuing it is an exercise in futility.

But to face the problem of the arts and artistic production with only pessimism in mind would simply be disastrous. What we should do instead is hold on to that utopian agenda of art and strive for a form of art that is emancipatory, and which is necessarily utopian. But what specific form of art is this? And additionally, what is to be done to achieve this form of art that we mentioned?

11 Theodor Adorno and Max Horkheimer further elaborate the failures of the project of enlightenment in their book, The Dialectic of Enlightenment. The project of Enlightenment, which began as a break from the Dark Ages, was, according to Adorno and Horkheimer, "the disenchantment of the world; the dissolution of myths and the substitution of knowledge for fancy." See Max Horkheimer and Theodor Adorno, Dialectic of Enlightenment, trans. by John Cumming (New York: Continuum, 1972), 3.

${ }^{12}$ I use the quotation "antennae of the race" ironically as the one who said it was Ezra Pound, a known fascist supporter. In the 1940s, when Ezra Pound worked as a broadcaster for Rome Radio, he infamously espoused anti-Semitic and fascist propaganda, much to the chagrin of people who belong to his circle, including Ernest Hemingway, the famous novelist and an erstwhile friend. Hemingway eventually said of Pound that the latter deserves "punishment and disgrace but what he really deserves more is ridicule." See Josh Jones, "Ernest Hemingway Writes of His Fascist Friend Ezra Pound: 'He Deserves Punishment and Disgrace' (1943)," in Open Culture (22 August 2013), <http://www.openculture.com/2013/08/hemingway-writes-ofhis-friend-the-fascist-ezra-pound-he-deserves-punishment-and-disgrace-1943.html $>$.

(c) 2019 Jesus Emmanuel S. Villafuerte

https://www.kritike.org/journal/special issue/villafuerte april2019.pdf

ISSN 1908-7330

(cc) BY-NC-ND 


\section{The Birth of the Curator}

"It is evident that nothing concerning art is self-evident anymore, not its inner life, not its relation to the world, not even its right to exist."

- Theodor Adorno, Aesthetic Theory

Not only had the expansion of capital in the cultural field created new forms of art or elevated the status of previously existing ones, it also paved the way for the birthing of a new kind of intellectual as a consequence of the institutionalization of museums and galleries: the curator. ${ }^{13}$ A product of necessity, the curator would serve as the mediator between the artwork and the spectator. In his book Factories of Knowledge, Industries of Creativity, Austrian philosopher and theorist Gerald Raunig utilizes The Courage of Truth, one of Foucault's last lectures, to explain the dynamics of knowledge production. Raunig explains that, according to Foucault, there are three main figures of knowledge transference: the teacher, the wise man, and the prophet. The teacher is the "expert" who "passes a uniform and static form of knowledge from one pupil to another as part of long chain of tradition." The wise man is the hermit, the one who has shunned the world and has "withdrawn into himself;" he has "knowledge of the being of the world and of things." Lastly, the prophet has "the role of the teacher, but at the same time he does not speak for himself, in his own name."14 The curator belongs to two of these categories: the teacher and the prophet. As a teacher, the curator explains to the uninitiated the essence of the exhibit, the rhyme and reason behind the assemblage of artworks, even the individual merits of the artistic pieces that constitute the exhibit; as a prophet, the curator enunciates, whether he is conscious of it or not, the language of his Absolute-hence, the curatorial assessment is the very manifestation of the curator's subjectivity. The prophet is God's representative on Earth, the purveyor of truth. The curator is the prophet of the galleries and the museums.

Art critic Boris Groys likens museums to cemeteries and curators to gravediggers. According to Groys, a museum is "much more a cemetery than

${ }^{13}$ In an informal conversation with activist and art critic Angelo Suarez, I asked him if my assumption regarding the rise, or birthing as mentioned above, of the curator as an event necessitated by the rise of museums and galleries is correct, he replied that it is not so much a birthing of a new breed of intellectual than the professionalization of what was already a previously existing one. Angelo Suarez is a poet, artist, and critic. He won the Palanca for poetry when he was just 19 years old after which he became an instant celebrity among the literati, with some even calling him the new enfant terrible of Philippine letters. He would later on abandon traditional poetry and produce some of the most refreshing works of poetry and fiction in the last decade: Circuit: The Blurb Project, Philippine English: A Novel, and Dissonant Umbrellas: Notes Toward a Gesamtkuntswerk, among others. As an art critic, he is known as one of the few intellectuals who engage in institutional critique.

${ }^{14}$ Raunig, Factories of Knowledge, 56-57.

(c) 2019 Jesus Emmanuel S. Villafuerte

https://www.kritike.org/journal/special issue/villafuerte april2019.pdf

ISSN 1908-7330

(cc) BY-NC-ND 
any other" because "real cemeteries do not expose the corpses of the dead, but rather conceal them, just as the Egyptian pyramids did." 15 In museums, the corpses of the past regimes are exposed, aestheticized, and glorified. Museums do not only remind us of the past, there are moments when a museum even privileges the past over the present. Take as an example Hito Steyerl's reaction when she saw a refurbished World War II tank displayed inside a museum:

One might think that the active role of a tank would be over once it became part of a historical display. But this pedestal seems to have acted as a temporary storage from which the tank could be redeployed directly into battle. Apparently, the way into a museum-or even into history itself-is not a one-way street. Is the museum a garage? An arsenal?16

The position of the curator is powerful. As mediator, he pulls down the artwork from the realm of the sublime and presents it, like an offering, to the spectator. He exists in that interstitial space between understanding and obscurity - the curator makes understanding possible and at the same time, he can be a hindrance to understanding. With these said, it begs us the question: is the curator an agent of capital who plays an active role in the reproduction of the fetishizing logic of the galleries and museums? The answer is dialectical: while we can say that the curator is necessarily always already trapped in logic propagation as in Foucault's figure of the teacher who imparts knowledge which is the knowledge he received from his predecessors, the emancipated curator (as I would like to call) who is selfreflexive-meaning, someone who is aware of the inherent contradictions in his role and power would, by virtue of his awareness, be able to subvert the logic imposed on him-instead of being a mere tool in propagating and reproducing the logic of museums and galleries, would be able to appropriate the very same space given to him as a locus of launching his critique-a locus where he could offer, borrowing a term from Frederic Jameson, radical alternatives to the status quo. In the end, what we should look for as the primary characteristic of a curator is his recognition of art's historico-ethical function: that is, art is representative as it springs from the collective experiences of the people; it must serve not an individual but a community.

${ }^{15}$ Boris Groys, In the Flow (London: Verso, 2016), 18.

${ }^{16}$ Hito Steyerl, Duty Free Art: Art in the Age of Planetary Civil War (London: Verso, 2017),

1.

(C) 2019 Jesus Emmanuel S. Villafuerte

https://www.kritike.org/journal/special issue/villafuerte april2019.pdf

ISSN 1908-7330

(cc) BY-NC-ND 


\section{Bring Art Back to the People}

We should burn museum and galleries. Not literally, of course. What is being proposed in this paper is not material destruction in the manner of the Nazis during World War II or the Romans when they burned the library of Alexandria. It is not because we should be averse to violence, nor because revolutions should be despised. There are times that call for bloody revolutions and upheavals. A utopian world, a future which is unlike the present as one theoretician calls it, would not be possible on the parleying table. But in this specific case, we must recognize the potentialities of museums and galleries, the possibility of them serving as repositories of knowledge and collective wisdom, a place where cultural artefacts can be found, not for capitalist consumption but as a reminder, following Deleuze and Guattari in What Is Philosophy?, for the people to come and make sense of how they should continuously struggle against renewed forms of power and systems of domination. As this is not the current orientation of museums, we should all aspire of seeing the museums and galleries of the future the way we aspire and fight for a society which is unlike what we have today. The museums and galleries are the locus of our contention. This is the place where we will launch our war.

What is meant by burning museums and galleries is simple: to get rid of the old in favor of the new. What we should seek is the refunctioning of the logic of museums and galleries and to overhaul our archaic perception of art. What we should do in order to achieve it is to critique, in every way imaginable and as relentlessly belligerently as possible, the notion of art as a part of the logic of capital which renders it always already commodified and which has confined it in its gilded cage. We must recognize that the artwork is not a commodity but an assemblage of sensory fabrics and, according to Rancière, this common fabric is what binds us together as a community. Simultaneously, our critiques should contain a recognition of art's historicity, an attempt to bring art back to the people, that is, back to its previous historical function-after all, Rancière believes, art and aesthetics defined as "ways of doing and making" spring from the collective endeavors of people. Rancière writes in his book Aisthesis:

Poetry is the flowering of a form of life, the expression of a poeticity immanent to the ways of life of a people and its individuals. Poetry exists in poems only if it already exists latently in forms of life .... It exists in the sensations, gestures and attitudes of these peasants, grooms, coachmen, hunters and butchers, who celebrate the symbolic potential of nature 'in the choice of their

(c) 2019 Jesus Emmanuel S. Villafuerte

https://www.kritike.org/journal/special issue/villafuerte april2019.pdf

ISSN 1908-7330

(cc) BY-NC-ND 
life, and not in their choice of words.' Finally, it exists in words, of which everyone is a silent poem, the translation of an original relation with those other words that are visible things. ${ }^{17}$

Poetry or art in general is an expression of a poeticity immanent to the collective experiences of people. And by bringing art to the people, by asserting its historical function as a way of life, a way of representing an individual role in the community, and wresting it away from the clutches of capital and commodity fetishism, we are not only fostering what Rancière calls "demiurgic projects of a 'new life'," but more importantly, we are "[weaving] a common temporality of art best encapsulated in the formula: a new life needs a new art." 18 This temporality ensures the unimpeded production of art and artistic modes thereby paving the way for the creation of new forms of "doing and making" which the community needs. This will give art a certain sense of ethical utility similar to the ethical regime in the time of Plato, far from its current function as a commodified spectacle.

But the task does not end with bringing art back to the people; it is only the beginning, as the final goal is to create an aesthetic community, the function of which will be discussed in the succeeding paragraphs.

The first step in bringing art back to the people is to follow what Adorno proposes in his book, Minima Moralia: Reflections on a Damaged Life, which is to take the market out of the equation in the process of producing art, or to produce art that is not marketable at all because "he who offers for sale something that no one wants to buy, represents even against his will, freedom from exchange." 19 Art that has escaped commodification is the form of art that Ranciere talks about when he says that it is something that is rooted in the community. But if it being sold out is inevitable, then, at least the art produced should function as an immanent critique of its very own contradictions, or the process that made it possible. ${ }^{20}$

\footnotetext{
${ }^{17}$ Jacques Rancière, Aisthesis: Scenes from the Aesthetic Regime of Art, trans. by Zakir Paul (London: Verso, 2013), 60.

18 Jacques Rancière, Dissensus: On Politics and Aesthetics, ed. and trans. By Steven Corcoran (London and New York: Continuum, 2010), 121.

${ }^{19}$ Theodor Adorno, Minima Moralia: Reflections on a Damaged Life, trans. E.F.N. Jephcott (London: Verso, 2004), 68.

${ }^{20}$ Rancière, Dissensus, 178. Drawing from Adorno, Rancière explains at length the idea of art's social function: "The idea of an art that accompanies the resistance of the dominated and promises a liberty and an equality come to the very extent that it affirms its absolute resistance to engaging in any compromise with the tasks of political militantism or of the aestheticization of forms of daily life. This is summed up by Adorno's expression: 'art's social function is not to have one.' On this view, art does not resist purely by ensuring its distance because it occupies the site of an impassable contradiction. For Adorno its autonomous appearance and the reality of the division of labor, mast, Ulysses' mastery is separated from the work of the sailors, their 
Raunig narrates in his book, Factories of Knowledge, Industries of Creativity, how in the '30s, in response to rise of fascism in Europe, activists led by Bertolt Brecht tried to develop an anti-fascist theater practice, "yet this theater did not want to stop at conveying political contents, but sought to overturn the hierarchical and organizational forms of bourgeois time at the same time." 21 This form of theater, while acting as a platform for the expression of political and anti-fascist sentiments, also acted as an immanent critique of the bourgeois politics and logic that operate within the medium of the theater and the artistic plane as a whole. Hence, the function of the genuine political theater is necessarily dialectical.

\section{Subvert the Logic of the Theater, Emancipate the Spectator}

Nikolai Ceausescu, the late leader of Romania, was known for many things: his extravagance, his eccentricity, and his Stalinist "cult of personality," among others. His regime had established a lot of notable programs on culture and the arts, one of which is the pioneering of a type of socialist theater which was viewed by outsiders as rather quirky, weird, even bizarre. In his form of theater, when all the performances were over, the performers would gather on the stage, as all theater performers do. However, instead of wallowing in the glory and applause showered on them by the audience as appreciation for their impeccable performance, they would defy the logic of the theater, that is, they would face Ceausescu, smile at him and clap, as if it was Ceausescu, and not them, who just finished giving a brilliant performance. Ceausescu with his wife and aides would smile back and acknowledge the applause of the performers. In this process, there is a reversal of roles: the performer becomes the spectator, and the spectator, the performer. The theater's logic of domination is subverted. Of course, this might sound to be a perversion of the project of emancipation proposed by Rancière. After all, Ceausescu was deemed to be an evil dictator by western countries-if we follow this, what we will see is the power of the dictator at play. Additionally, it highlights the powerlessness of the thousands of ordinary spectators who are caught in the middle of two converging spectacles, because in this instance, the theater is duplicated: on one hand you have the performers on the stage, and on the other, you have Ceausescu himself who usurps the power of the theater and creates an invisible theater with him as the primary actor.

\footnotetext{
ears covered, and the song of the sirens. To denounce the capitalist division of labor and the commodity embellishment more effectively, Schoenberg's music must even be more mechanical, even more 'inhuman' than the Fordist assembly line."

${ }^{21}$ Raunig, Factories of Knowledge, 54.

(c) 2019 Jesus Emmanuel S. Villafuerte

https://www.kritike.org/journal/special issue/villafuerte april2019.pdf

ISSN 1908-7330
}

(c) BY-NC-ND 
Following Rancière, the idea of the emancipation of the spectator is to narrow, if not totally destroy, the gap between the spectator and the work of art. The Ceausescu spectacle, although a perversion of the logic of emancipation, offers us a glimpse of its possibilities, of the passive spectator becoming active - only, the spectator, in this case Ceausescu, does not offer a critique of the spectacle rather, he becomes part of the spectacle itself:

Emancipation begins when we challenge the opposition between viewing and acting; when we understand that self-evident facts that structure the relations between saying, seeing and doing themselves belong to the structure of domination and subjection. It begins when we understand that viewing is also an action that confirms or transforms this distribution of positions. The spectator also acts, like the pupil or scholar, she observes, selects, compares and interprets. She links what she sees to a host of other things that she has seen on other stages, in other kinds of place. She composes her own poem with the elements of the poem before her. She participates in the performance by refashioning it in in her own way-by drawing back, for example, from the vital energy that is supposed to transmit it in order to make it a pure image and associate this image with a story which she has read or dreamt, experienced or invented. They are thus both distant spectators and active interpreters of the spectacle offered to them..$^{22}$

An emancipated spectator is someone who recognizes that the theater renders him powerless and tries to subvert what the theater imposes on him.

Jacques Rancière urges us to prepare for a revolution that is sure to come, a revolution which "will be at once the consummation and abolition of philosophy; no longer merely 'formal' and 'political' it will be a 'human' revolution," and this "human revolution is an offspring of the aesthetic paradigm." 23 This revolution, abstract as it may seem to us now, is expected to change categories of meaning and destroy systems of domination in the artistic (where it will be waged first) and social fields. Perhaps this revolution which Rancière speaks of refers to the new regime of arts that will supersede the current regime of arts which asserts the continuity of history. Or perhaps, although seemingly highly unlikely, it refers to some revolution that will

\footnotetext{
${ }^{22}$ Rancière, Emancipated Spectator, 13.

${ }^{23}$ Rancière, Dissensus, 120.
} 
overturn the social order. After all, he believes that a social revolution necessarily brings about artistic and intellectual emancipation. At any rate, we must prepare the groundwork for this revolution - the aesthetic field is not a neutral unmediated space; itis also a field of contention-we must recognize this, and most importantly, we must be actors on the theater of this coming revolution.

\title{
The Task of the Artist: Toward an Aesthetic Community
}

\author{
"Social emancipation was simultaneously an aesthetic emancipation, \\ a break with the ways of feeling, seeing and saying that characterized \\ working-class identity in the old hierarchical order." \\ -Jacques Rancière, The Emancipated Spectator
}

The burning of museums and galleries could come in many forms, as earlier mentioned. It is a metaphor that signifies not the actual burning of museums and galleries, but the refunctioning of their logic. By burning museums and galleries, we are radicalizing and taking control of these spaces which are otherwise under the control of capital. The artist, of course, plays a vital role in this endeavor:

Although we no longer share early twentieth-century dreams of collective rhythmics or Futurist and Constructivist symphonies of the new mechanical world, we continue to believe that art has to leave the art world to be effective in "real life": we continue to try to overturn the logic of the theatre by making the spectator active, by turning the art exhibition into a place of political activism or by sending artists into the streets of derelict suburbs to invent new models of social relations. ${ }^{24}$

The artist must turn his back on the museum and the gallery and be with the people. He must immerse himself in their struggles, in effect "inventing new models of social relations." The artist must shed the title of god-creator and be a producer instead. Perhaps a toiler for he must dirty his hands with the grime of labor together with wageworkers, peasants, petite-bourgeoisie. He must view his art as necessarily a product of the same system that renders other people powerless and impotent. By turning his back on museum and galleries, by fleeing the art world and connecting with ordinary people, the artist will reproduce/replicate what has been a recurring idea in this paper:

${ }^{24}$ Ibid., 137.

(c) 2019 Jesus Emmanuel S. Villafuerte

https://www.kritike.org/journal/special issue/villafuerte april2019.pdf

ISSN 1908-7330

(c) BY-NC-ND 
his ethico-historical role of depicting not just beauty or pain, but most importantly, the importance of an individual to the society. The artist must abandon claims of autonomy and freedom because, following Adorno, this freedom is just a mirage considering the relative unfreedom of the whole. Does this entail that the artist must be political in his art in the manner, for example, of the Soviet socialist realist? The answer is not necessarily. Politicization here means that the artist must recognize his problematic position in the current artistic grid, and corollarily, that he must devise ways of resisting the tyranny of the current dispensation through his art.

This fleeing from the art world, reminds us of what Deleuze says in Dialogues, that the highest aim of literature, and by extension, art in general, is to "to leave, to leave, to escape ... to cross the horizon, enter into another life ...." In other words, to flee and to trace lines of flight. The artist must, just like the figure of the schizoid, come out of his confinement inside the walls of galleries and museums and experience the world. The artist must not be transfixed in a single space, he must not cease moving, because to be transfixed, to cease movement and exist in a singular space is to necessarily grow roots, to be a tree planted on where he stands; one must instead be in multitudes of spaces. This flight is necessary because, according to Deleuze, "to fly is to trace a line, a whole cartography, one only discovers the world through a long, broken flight." 25 An artist will only be capable of understanding his task the moment he effaces himself and becomes one with the multitude. The artist must, as Rancière proposed, be instrumental in the creation of an aesthetic community.

An aesthetic community is not a community of artists but a community bound by a common sensorial fabric, a community where the logic of the theater has been overturned and where each member treat each other as equals: "A 'common sense' is in the first instance, a community of sensible data: things whose visibility is supposed to be shared by all, modes of perception of these things, and the equally shareable meanings that are conferred on them." 26 The current social setup has made thinking individuals unable to see themselves as part of a community. The logic of the museums and galleries has created gods out of normal human beings:

According to the idea of a 'social nature', forms of domination were a matter of sensory inequality. The human beings who were destined to think and rule did not have the same humanity as those who were destined to work, earn a living and reproduce. As Plato had put

\footnotetext{
${ }^{25}$ Gilles Deleuze and Claire Parnet, Dialogues II, rev. ed., trans. by Hugh Tomlinson and Barbara Habberjam (New York: Columbia University Press, 2007), 36.

${ }^{26}$ Rancière, Emancipated Spectator, 102.
} 
it, one had to 'believe' that God had put gold in the souls of the rulers and iron in the souls of the artisans. That nature was a matter of 'as if'; it existed in the form of the "as if" and it is necessary to proceed as if it existed. The artisans did not need to be convinced by the story in their innermost being. It was enough that they sensed it and that they used their arms, their eyes and their minds as if it were true. And they did so all the better in so far as this lie about their condition being adapted to their kind of soul corresponded to the reality of their condition. This is the point where the as if of the community constructed by aesthetic experience meets the as if at play in social emancipation. Social emancipation was an aesthetic matter because it meant the dismemberment of the body animated by that 'belief'. ${ }^{27}$

The problem, as stated by Rancière, is sensorial-"sensory inequality" as he calls it, wherein some humans are deemed better than others precisely because some feel better than the others, some have "souls of gold" while others have "souls of iron." And the only way to destroy this specific mode of power relations/perception, of course, is by tinkling with the very foundation of this power relations, these problematic senses; by cutting the parts of the body that have become defective, by gouging the eyes that do not see and severing the gangrenous arms that could not feel. Social emancipation is aesthetic emancipation because by cutting the defective body parts and providing new parts whose sensorial capabilities are in tune with the sensorial capabilities of the others, we are effectively destroying forms of perceptions. Deleuze and Guattari in What Is Philosophy? propose that a writer/artist must "wrest the percept from perceptions, the affect from affections, the sensation from opinion in view, one hopes, of the still missing people." ${ }^{28}$ The aesthetic community will be populated by the still missing

27 Ibid.,70

${ }^{28}$ Gilles Deleuze and Felix Guattari, What Is Philosophy?, trans. by Graham Burchell and Hugh Tomlinson (London: Verso, 1994), 76. Here is an extended quotation from the same section: "The writer twists language, makes it vibrate, seizes hold of it, and rend it in order to wrest the percept from perceptions, the affect from affections, the sensation from opinion - in view, one hopes, of the still missing people .... This is precisely, the task of all art and, from colors to sounds, both music and painting similarly extract new harmonies, new plastic or melodic landscapes, and new rhythmic characters that raise them to the height of the earth's song and the cry of humanity: that which constitutes tone, health, becoming, a visual sonorous bloc. A monument does not commemorate or celebrate something that happened but confides to the ear of the future the persistent sensations that embody the event: the constantly renewed suffering

(c) 2019 Jesus Emmanuel S. Villafuerte

https://www.kritike.org/journal/special issue/villafuerte april2019.pdf

ISSN 1908-7330

(c) $\mathrm{BY}-\mathrm{NC}-\mathrm{ND}$ 
people, by the people to come, the homo aestheticus, whose limbs move in unison, whose skin could feel the warmth of the sun or the cold touch of the wind, whose ears could hear the sonorous inflection of voices from different moments in history, whose eyes could see and distinguish the varicolored trees on a foreign landscape. The homo aestheticus is an individual, yet he knows that he is part of the multitude, the community; he has learned to erase his face but not his individuality. In the process of becoming, the artist must keep in mind that he does not produce art for the market, for the museums and the galleries, nor for the present; he produces art in anticipation of the people to come, in anticipation of the aesthetic community which he is trying to build.

\section{Center for Creative Writing, Polytechnic University of the Philippines} School of Humanities, Ateneo de Manila University, Philippines

\section{References}

Adorno, Theodor, Aesthetic Theory, ed. by Gretel Adorno and Rolf Tiedemann, trans. and ed. by Robert Hullot-Kentor (London: Bloomsbury, 2004). Minima Moralia: Reflections on a Damaged Life, trans. E.F.N. Jephcott (London: Verso, 2004). Prisms, trans. by Samuel Weber and Shierry Weber (Cambridge:

MIT Press, 1997).

Deleuze, Gilles and Claire Parnet, Dialogues II, rev. ed., trans. by Hugh Tomlinson and Barbara Habberjam (New York: Columbia University Press, 2007).

Deleuze, Gilles and Felix Guattari, What Is Philosophy?, trans. by Graham Burchell and Hugh Tomlinson (London: Verso, 1994).

Groys, Boris, In the Flow (London: Verso, 2016).

Horkheimer, Max and Theodor Adorno, Dialectic of Enlightenment, trans. by John Cumming (New York: Continuum, 1972).

Jones, Josh, “Ernest Hemingway Writes of His Fascist Friend Ezra Pound: 'He Deserves Punishment and Disgrace' (1943)," in Open Culture (22 August 2013), <http://www.openculture.com/2013/08/hemingway-

of men and women, their re-created protestations, their constantly resumed struggle. Will this all be in vain because suffering is eternal and revolutions do not survive their victory? But the success of a revolution resides only in itself, precisely in the vibrations, clinches, and openings it gave to men and women at the moment of its making and that composes in itself a monument that is always in the process of becoming, like those tumuli to which each new traveler adds stone."

(c) 2019 Jesus Emmanuel S. Villafuerte

https://www.kritike.org/journal/special issue/villafuerte april2019.pdf

ISSN 1908-7330 


\section{TOWARD AN AESTHETIC COMMUNITY}

writes-of-his-friend-the-fascist-ezra-pound-he-deservespunishment-and-disgrace-1943.html>.

Marriott, Red, "Slogans of 68," in libcom.org (30 April 2008), $<$ https://libcom.org/history/slogans-68>.

Rancière, Jacques, Aisthesis: Scenes from the Aesthetic Regime of Art, trans. by Zakir Paul (London: Verso, 2013).

Dissensus: On Politics and Aesthetics, ed. and trans. By Steven Corcoran (London and New York: Continuum, 2010).

, The Emancipated Spectator, trans. by Gregory Elliott (London: Verso, 2009).

, The Future of the Image, trans. Gregory Elliott (London: Verso, 2009).

Raunig, Gerald, Factories of Knowledge: Industries of Creativity, trans. by Aileen Derieg (Los Angeles, CA: Semiotext(e), 2013).

Rockhill, Gabriel, Translator's Introduction to Jacques Rancière, The Politics of Aesthetics: The Distribution of the Sensible, trans. by Gabriel Rockhill (London: Continuum, 2004). 